\title{
ДОСЛІДЖЕННЯ ПСИХОЛОГІЧНИХ ОСОЛИВОСТЕЙ ЖІНОК В ПРЕГРАВІДАРНІЙ ПІДГОТОВЦІ ДЛЯ ПОПЕРЕДЖЕННЯ У НИХ ПСИХОСОМАТИЧНИХ РОЗЛАДІВ ПІД ЧАС ВАГІТНОСТІ
}

УДК: 618.39-06:616.89-008]-07

\author{
Бондаренко Наталія Петрівна \\ Кандидат психологічних наук, асистент кафед- \\ ри акушерства і гінекології № 1 Національного \\ медичного університету ім. О. О. Богомольия, \\ м. Київ (Украӥна)
}

\section{Наритник Тетяна Теодорівна}

Кандидат психологічних наук, асистент кафедри акушерства і гінекології № 1 Національного медичного університету ім. О. О. Богомольия, м. Київ (Україна)

\section{Слободяник Олег Янович}

Кандидат психологічних наук, дочент кафедри акушерства $i$ гінекології № 1 Національного медичного університету ім. О. О. Богомольия, м. Київ (Украӥна)

\section{Зіатдінова Маріана Русланівна}

Студентка 6 курсу медико-психологічного факультету Національного медичного університету ім. О. О. Богомольия, м. Київ (Украӥна)

\begin{abstract}
Анотація. У проведеному дослідженні проаналізовано проблему впливу на емоиійний стан жінки протікання фізіологічної вагітності та зміни гормонального фону під час запліднення і в період виношування плода. У роботі досліджується психологічний стан та риси характеру жінок до зачаття $і$ як цей набір психологічних якостей може впливати на протікання, завершення вагітності та після народження з метою їх можливої корекиії в прегравідарній підготовці. Значна роль приділяється акцентуації характеру, ї̈ відношення на появу якісних патопсихологічних змін в момент вагітності та після неї. Розглянуто ймовірність виникнення психічної хвороби у зв'язку з народженням дитини. Авторами
\end{abstract}


DOI (Issue): https://doi.org/10.31108/2018vol12iss2

розроблено методи профілактики та попередження виникнення психічних станів на основі вивчення перинатальної матрищі.

Ключові слова: вагітність, пологи, післяпологовий стан, психічний стан, психічні розлади, перинатальні матриці, голотропне дихання, профілактика, корекиія.

Постановка проблеми у загальному вигляді. Вагітність - це складний процес, який відбувається в організмі жінки. Майбутня мама повинна знати, що під час вагітності часто виникає безліч питань, незрозумілих речей, та не усвідомлення жінки фізіології свого організму, що може спровокувати появу патологічного стану в антенатальний та постнатальний періоди і який в свою чергу може стати причиною неправильного розвитку дитини та не пристосуванням іiї у соціумі. Тому в період до початку вагітності та на її перших етапах $\epsilon$ важливим психологічний супровід жінки, проведення психопрофілактичних занять та вміння вчасно визначити психопатологічні розлади для надання відповідної медикопсихологічної превентивної допомоги.

В літературі наголошується характерна для вагітності перебудова самосвідомості жінки з поступовим включенням в нього образу дитини («симптом ухвалення нового життя в собі»). На певному етапі вагітності відбувається перенесення домінанти з себе на майбутню дитину. Це $є$ кульмінаційною вершиною вагітності, будучи своєрідним індикатором сприйняття, переробки і оцінки жінкою досвіду цього психофізіологічного стану. Тому i виникає потреба у психологічному супроводі вагітних. У наукових дослідженнях тема психологічного супроводу щодо проблеми мате- ринського інстинкту розгорілась досить недавно, тільки у другій половині XX століття. Одні дослідники (Г. Г. Філліпова, Н. П. Коваленко, Н. В. Боровікова, К. Н. Белогай) насаджують примат соціальних факторів у формуванні материнського відношення, інші (М. Мід, С. Гроф, Е. Бадинтер) дотримуються думки про те, що материнська турбота є вродженим механізмом, спільним для людини і приматів. Аналіз психологічних робіт дозволяє виділити два основні напрямки досліджень. Перший напрямок присвячений обговоренню якостей, поведінки матері, їх впливу на розвиток дитини (С. А. Мінюрова, Є. А. Тетерлєва). Другий напрямок аналізу материнства акцентує увагу на ідеї суб'єктності матері і дитини. Найбільш яскраво ця ідея висвітлена у концепції материнства Г. Г. Філліпової. У цій концепції материнство розглядається не тільки як умова для розвитку дитини, але і як особлива потребово-мотиваційна складова психології жінки, що формується на протязі усього життя. Необхідність дослідження психологічних особливостей ставлення жінки до власної вагітності зумовлена існуванням явища девіантного материнства (Д. Пайнс, К. Боне). На думку багатьох дослідників (Е. Берн, І. Ю. Хамітова, В. С. Торохтій, I. С. Ісєніна, Т. І. Барановська, К. Штайнер), існує зв'язок між типом ставлення до вагітності, психологічним станом май- 
бутньої матері і видом життєвого сценарію: більша кількість жінок сьогодення запрограмовані на досягнення успіху, збереження фігури і впродовж тривалого часу відмовляються від народження дитини. Вагітність викликає у них негативні емоційні переживання, розвивається патологічні психічні стани, що призводять до виникнення різних хвороб на психосоматичному рівні, що у свою чергу не може не позначитись на психічному та фізичному здоров’ї майбутньої дитини.

Актуальність дослідження. Ми пам'ятаємо, що кожна людина - це індивідуальність, яка народжується 3 властивими лише для неї певними ознаками. В процесі навчання й соціалізації вона стає цілісною структурою особистістю, маючи «свої», не характерні для інших, психологічні властивості. Під дією стресового чинника (а вагітність - це ендогенний стрес для організму (вибух гормонів, про які ми писали вище)), можуть 3'являтися перманентні психопатологічні характеристики патологічні психічні стани. Останні в свою чергу можуть зникати, якщо жінка вчасно усвідомлює проблему й намагається іiі вирішити самостійно чи за допомогою спеціаліста, або ж загострюватися (якщо у жінки в анамнезі $є$ схильність до психічних захворювань) й перевтілюватися у хворобу.

Психічний стан тісно пов'язаний 3 індивідуальними властивостями особистості, оскільки він характеризує психічну діяльність не загалом, а індивідуально. Стан страху в од- нієї людини може виявлятися у психічному збудженні, а в іншої - у психічному «паралічі», гальмуванні психічної діяльності. Так само, як психічні властивості відбиваються на психічних станах, психічні стани можуть переходити у психічні властивості. Якщо вагітна дуже часто переживає стан тривоги, можливе формування особистісної властивості тривожності, що в свою чергу може негативно відобразитися на майбутній дитині та ній самій. Тому працюючи практично на базі Перинатального центру міста Києва, та маючи ряд випадків із зазначеної проблеми і виникла потреба у дослідженні психологічних осоливостей жінок в прегравідарній підготовці для попередження у них психосоматичних розладів під час вагітності.

Мета роботи: дослідити психологічні особливості ще невагітних жінок на появу у них патологічних психічних станів під час вагітності та після неї з метою корекції в їх прегравідарній підготовці.

Матеріали і методи: аналіз психологічної та наукової літератури по даній проблемі, спостереження, бесіда, інтерв'ю; особистісний опитувальник ММРI (тест Міні-СМІЛ377), опитувальник Шмішека на акцентуацію характеру.

Виклад основного матеріалу дослідження. Відповідність між психічним станом і рисою особистості не є правилом. Процес цей оборотній, а це свідчить про те, що його можна скоректувати. За допомогою психоте- 
рапії та психотерапевтичних методик можна прийти до відмінних результатів. Найбільш доцільно використовувати когнітивноповедінкову терапію, яку можна доповнити знаннями 3 клієнт-центрованої та гештальт терапії.

Тож пропонуємо детально розібрати механізм вагітності, від зачаття до народження малюка, як відбувається ця перебудова i яку роль відіграють в цьому гормони. Запліднення - це процес злиття чоловічої та жіночої статевих клітин (гамет) з утворенням зиготи. Відбувається воно у верхній частині фалопієвої труби і можливе лише за наявності у жінки овуляції (вихід яйцеклітини з яєчника в порожнину тіла в результаті розриву зрілого фолікула ячника).

На 10-й день після запліднення зародок виявляється цілковито втопленим у стінку матки (імплантація). Одразу після завершення імплантації йде формування плаценти. Плацента - місце - $є$ особливим органом, який забезпечує плід поживними речовинами і киснем, всмоктує кінцеві продукти метаболізму i служить бар'єром для шкідливих речовин. Вона розвивається із трофобласта, зовнішнього шару бластоцисти (клітинної маси зародка, що забезпечує його імплантацію в ендометрій). Продуковані плацентою гормони підтримують функціональну цілість ендометрію. Якщо рівень естрогену і прогестерону виявиться занадто низьким, можливе відшарування ендометрію і вагітність буде перервана. Пізніше ми більш детально опишемо відношення гормонів до ЦНС та як вони впливають на емоційний стан.

Починаючи 3 8-го тижня вагітності до народження дитини плід розвивається в амніотичному мішку, що розміщений всередині матки. Мішок заповнений прозорою рідиною, яка захищає плід від ушкоджень; ця так звана амніотична рідина заковтується плодом, вмоктується у кров і виводиться у вигляді сечі. Кисень і поживні речовини плід отримує з материнської крові через плаценту.

Основні органи плода розвиваються протягом перших місяців вагітності. У цей період плід найуразливіший для інфекцій, зокрема для віруса епідемічного багрянця, а також для алкоголю та інших токсичних речовин. Поступово розміри і рівень організації плода зростають. Приблизно на 32-му тижні розвитку плід перевертається головою донизу і дедалі більше набуває вигляду, який він матиме після народження.

Нормальна вагітність триває 40 тижнів (відлік ведуть від першого дня останнього менструального циклу жінки). Увесь термін вагітності прийнято поділяти на триместри, по три місяці у кожному. Протягом цього часу в організмі жінки відбувається багато змін, спрямованих на створення відповідних умов для плода та підготовку до пологів.

Тепер пропонуємо розглянути зміну гормонального фону під час запліднення та в період виношування плода і як гормональний 
фон впливає на нормальне існування жінки.

Зміна гормонів відбувається відразу ж після запліднення. Основна залоза, що виробляє гормони під час вагітності - гіпофіз ( у вагітних він збільшується у 2 рази). Клітини передньої долі гіпофіза секретують ЛГ, а в момент зачаття - ХГЧ, під впливом якого синтезується жовте тіло, що залишається активним протягом 10-12 тижнів, виробляючи необхідний для розвитку і збереження вагітності прогестерон (який стимулює зростання ендометрію і запобігає виходу нових яйцеклітин і менструаціі)та естроген. Жовте тіло зберігається до тих пір, поки плацента не буде в змозі самостійно виробляти естроген і прогестерон, приблизно до 4 місяця вагітності.

Вироблення прогестерону відбувається протягом всієї вагітності і поступово знижується до настання пологів. Не дивлячись на те, що він вкрай необхідний для виношування плода, гормон дає ряд негативних наслідків, наприклад, набряки, нудота, сонливість, печія, прискорене сечовипускання. Під його впливом шкіра вагітної стає більш еластичною, чутливою, сухою; відбувається внутрішнє розтягнення сполучної тканини, з'являються стриї. Прогестерон сприяє розвитку запорів.

Інший важливий гормон - естроген. В момент зачаття кількість їх збільшується у 20 разів, а в кінці вагітності приблизно у 300. Саме естроген відповідає за підготовку до народження. Їх високий рівень як у вагітної, так і не вагітної жінки сприяє затримці води в організмі та збільшенню апетиту, а це провокує до відкладення підшкірного жиру, що веде до надмірної маси тіла. Гормон спричинює виникнення акне та пігментації.

Всі ці зміни залишають слід в нервовопсихічній системі (поганий настрій, тривожні стани, депресії), вони заважають жінкам як в побуті, так і в інших життєвих ситуаціях. На це у вагітних включаються такі захисні механізми психіки - посилення дратівливості, головний біль, регресія (перехід на більш простий рівень функціонування), інфантилізм (відхід в дитинство), перенесення агресії на оточуючих.

Корисним для майбутніх мам будуть вчення С. Грофа, американського психолога та психіатра чеського походження, про перинатальні матриці, які також можна впровадити в прегравідарну підготовку. В своїх працях він виокремлює чотири базові перинатальні матриці в залежності від стадії пологів, порушення в яких може спричинити негативні наслідки.

БПМ 1 - Матриця блаженства/раю формується $з$ моменту зачаття і триває всю вагітність до перших переймів. Це матриця єдності матері і дитини. Впродовж дев’яти місяців весь всесвіт для дитини - це матка. Відчуття захищеності, ситість, ідеальна комфортна температура, зручна розслаблена поза. За умов сприятливої вагітності на цьому етапі у дитини формуються базова довіра до світу, вміння 
радіти і довіряти, розслаблятись і приймати себе, відчувати себе частиною природи.

Травми БПМ. Загроза аборту, викидню, токсикоз, захворювання і нестабільний емоційний стан мами - так звана токсична матка - можуть сформувати у дитини стійкі емоційні переживання власної ущербності, непотрібності, страху смерті, почуття провини за сам факт свого існування.

БПМ 2 - матриця жертви. Виходу немає або Вигнання з раю. Формується з моменту перших переймів до повного розкриття шийки матки. Триває у нормі - 4-5 годин (до 10 при перших пологах). Комфортне середовище і безпечний маленький світ раптом стає агресивним - починає стискатися і вбивати. А виходу немає. Дитина переживає ситуацію смертельної небезпеки і повної безвиході. На цій стадії пологів закладається вміння чекати i терпіти у складних ситуаціях.

Травми БПМ 2 - коротка матриця. Виникає при кесарському розтині чи швидких пологах. У людини формується нетерплячість, невміння доводити справу до кінця і боротися - всі проблеми потрібно вирішувати швидко і не потрібно докладати зусиль. Довга матриця. Виникає за тривалих пологів. Формує роль жертви. Людина впродовж життя може часто опинятися у ситуаціях, де на неї чинять тиск, а вона не чинить жодного опору.

БПМ 3 - матриця боротьби. Формується 3 моменту повного розкриття шийки матки до самого народження дитини на світ. Триває від 20 хв до 2 годин при перших пологах. На цьому етапі у дитини з'являється вихід. Це перший у житті шлях на свободу - шлях героя, повний небезпек, болю, страху, але й надії на перемогу.

У цій матриці дитина вчиться бути агресивною, сміливою і цілеспрямованою, вірити в себе, боротися і докладати зусиль. Також на цьому етапі закладається відчуття гидливості і відношення до сексуальності.

Травми БПМ 3. За умови використання щипців може сформуватися паттерн - допомогу приймати небезпечно, тому слід від неї відмовлятися. Довга матриця. Надто тривалий період пологів формує відношення «життя це боротьба». Такі люди часто опиняються в ситуаціях, де необхідно 3 кимось чи за щось боротися. Вони не відчувають легкості буття i радості простих рішень.

БПМ 4 - матриця свободи - повернення у рай. Дитина після усіх випробувань опиняється на свободі. Контакт $з$ новим світом це великий стрес, адже дитина опиняється у невідомому для неї середовищі - інша температура, світло, гравітація. На цьому етапі важливо, щоб маля відразу потрапило на руки до мами і відчуло знайомий запах і тепло, а отже захищеність.

Травми БПМ 4. Дитину розлучили 3 мамою відразу після пологів. Після усіх випробувань народження вона знову опиняється у небезпеці. 3 нею проводять незрозумілі маніпуляції - зважують, миють, обмірюють, кла- 
дуть на холодний стіл у порожній палаті. Так формується паттерн - все було намарно. Людина не бачить сенсу докладати зусиль, адже і так все закінчиться погано. Свобода для таких людей - не вища цінність, а самотність і холод.

Травми базових перинатальних матриць також можна і потрібно коректувати, як i у випадку акцентуацій характеру, за допомогою спеціальних психотерапевтичних технік для дорослих, наприклад, голотропне дихання (практика передбачає використання простих засобів - прискорене дихання, спеціально підібрану музику, малювання мандал та групову інтеграцію).

Результати дослідження та їх інтерпретація. Експеримент проводився на базі Перинатального центра м. Києва, участь прийня- ло 100 жінок. За допомогою опитувальника MMPI ( 377 питань) ми дослідили психологічний стан та риси характеру жінок до планованого зачаття. У 60 жінок виявився особистісно-аномальний регістр-синдром (акцентуація певних характеристик характеру). Цим жінкам було запропоновано додатково пройти опитувальник Шмішека (акцентуації характеру), де у 20 жінок виявився тривожний тип акцентуації, 15 - гіпертимічний тип, 5 - дистимічний тип, 10 - педантичний тип, 3 - демонстративний тип, 4 - збудливий тип, 2 - емотивний тип, 1 - екзальтований тип. 30 жінок погодилися впровадити в прегравідарну підготовку знання психологічних особливостей для попередження психосоматичних розладів у них самих та для протікання нормальних фізіологічних пологів і народженняздорової дитини.

Таблиия 1.

\begin{tabular}{|c|l|}
\hline $\begin{array}{c}\text { Акцентуація } \\
\text { (до зачаття) }\end{array}$ & \multicolumn{1}{|c|}{ Психічний стан $\rightarrow$ психосоматичне захворювання } \\
\hline Гіпертиміний тип & Агресія, роздратування $\rightarrow$ неврастенія, передчасні пологи \\
\hline Тривожний тип & $\begin{array}{l}\text { Нерішучість, лякливість } \rightarrow \text { пронос, печія, втрата свідомості } \\
\text { на ранніх строках, викидень, спазми, біль у суглобах, безплід- } \\
\text { дя }\end{array}$ \\
\hline Дистимічний тип & $\begin{array}{l}\text { Надмірна серйозність, похмурість, малослівність } \rightarrow \text { прищі, } \\
\text { фригідність, цистит }\end{array}$ \\
\hline Педантичний тип & $\begin{array}{l}\text { Стенічний стан, тривожний стан } \rightarrow \text { відкладення жиру } \\
\text { (ожиріння) }\end{array}$ \\
\hline Збудливий тип & $\begin{array}{l}\text { Афективний стан (гнів, агресія, грубість, імпульсивність) } \rightarrow \\
\text { кандидоз, передчасні пологи }\end{array}$ \\
\hline Емотивний тип & $\begin{array}{l}\text { Підвищена емоційність (чуйність, тривожність, балакучість), } \\
\text { фрустрація } \rightarrow \text { астма, безпліддя }\end{array}$ \\
\hline Демонстративний тип & $\begin{array}{l}\text { Підвищеної емоційності (фантазерство, тяга до похвали, брех- } \\
\text { ливість) } \rightarrow \text { виразки, фурункули, бурсит, позаматкова вагіт- } \\
\text { ність }\end{array}$ \\
\hline Екзальтований тип & $\begin{array}{l}\text { Підвищеної емоційності, афект (здатність до захоплення, від- } \\
\text { чуття щастя, радості, насолоди, легко переходять від стану } \\
\text { захоплення до суму) } \rightarrow \text { шизофренія }\end{array}$ \\
\hline
\end{tabular}


Було створено 2-ві групи: 1 група - $€$ акцентуація характеру, без корекції, 2 група була акцентуація, яка піддалася корекції. В таблиці (Табл.1) показані результати, в якій приведена I гр., де видно, що жінки, які мали акцентуацію до планування вагітності й відмовилися від психотерапії зазнали хвороботворних станів (приведені середні, узагальнені значення, які зустрічалися у більшості жінок) як для них самих, так і для плода; в однісї непідготовленої жінки стався дебют шизофренії. Результати II гр. в таблиці не приведені, тому що під дією психотерапії (когнітивноповедінкової, 3 елементами клієнтцентрованої та гештальт терапії) вдалося нормалізувати показники та вчасно попередити патологічні психічні стани, які могли спровокувати психосоматичні захворювання.

\section{Висновки та перспективи подальших} досліджень. Отже, у психічних станах поєднуються, зливаються характеристики психічних процесів і властивостей особистості. Аналіз психічного стану дає змогу прогнозувати поведінку особистості, іiі розвиток та самозростання.

Таким чином, на грунті того психічного процесу, який домінував у жінок до вагітності, підсилилася відповідна йому психічна властивість, яка в свою чергу (без іiї подальшої корекції), спровокувала появу певних психічних станів, що призвело до появи психосоматичних захворювань і патологічному протіканню вагітності.
Сумуючи вище зазначене, можна сказати, що дослідивши психологічні особливості ще невагітних жінок та своєчасне виявлення патологічно зміненого психічного стану, при втіленні цих знань в прегравідарну підготовку, можна попередити появу психосоматичних захворювань та народити здорову дитину.

В перспективі наших досліджень планується розроблення алгоритму надання психологічної консультативно-профілактичної допомоги майбутнім мамам на етапі прегравідарної підготовки.

\section{Перелік використаних джерел:}

1. The HUMANBODY Copyright 1995 Dorling Kindersley Ltd, London (ЛЮДИНА Навчальний посібник з анатомії та фізіології 3-тє оновлене видання/Львів 2003)

2. Александровский Ю. А. Пограничные психические расстройства. /Ю.А. Александровский//- М.: Медицина, 1993. -400 с.

3. Биологический энциклопедический словарь / гл. ред. М. С. Гиляров; редкол.: А. А. Бабаев, Г. Г. Винберг, Г. А. Заварзин и др. - 2-е изд., исправл. - М.: Сов. Энциклопедия, 1986.

4. Блейхер В. М., Крук И. В., Боков С. Н. Практическая патопсихологія / В. М. Блейхер, И. В. Крук, С. Н. Боков// - Ростов-на-Дону: Феникс, 1996.

5. Загальна психологія /За загальною редакцією академіка С.Д. Максименка. Підручник.-3-те вид., переробл. і доп. - Вінниця: Нова Книга, 2006. - 688 с.

6. Клиническая психология: Учебник для студентов медицинских вузов и факультетов клинической психологи /Под ред. Б. Д. Карвасарського// - СанктПетербург, 2006.

7. Яньшин П. В. Практикум по клинической психологии: Методы исследования личности / П.В. Яньшин// - 
СПб.: Питер, 2004. - 331 с.

\section{References (Transliteration):}

1. The HUMANBODY Copyrightc 1995 Dorling Kindersley Ltd, London (LYuDYNA Navchal'nyy posibnyk z anatomiyi ta fiziolohiyi 3-tye onovlene vydannya/L'viv 2003)

2. Aleksandrovskyy Yu. A. Pohranychnыe psykhycheskye rasstroystva. /Yu.A. Aleksandrovskyy//- M.: Medytsyna, 1993. $-400 \mathrm{~s}$.

3. Byolohycheskyy entsyklopedycheskyy slovar/hl. red. M. S. Hylyarov; redkol.: A. A. Babaev, H. H. Vynberh, H. A. Zavarzyn y dr. - 2-e yzd., yspravl. - M.: Sov. Эntsyklopedyya, 1986.

4. Bleykher V. M., Kruk Y. V., Bokov S. N. Praktycheskaya patopsykholohiya / V. M. Bleykher, Y. V. Kruk, S. N. Bokov// - Rostov-na-Donu: Fenyks, 1996.

5. Zahal'na psykholohiya /Za zahal'noyu redaktsiyeyu akademika S.D. Maksymenka. Pidruchnyk.-3-te vyd., pererobl. i dop. - Vinnytsya: Nova Knyha, 2006. - 688 s.

6. Klynycheskaya psykholohyya: Uchebnyk dlya studentov medytsynskykh vuzov y fakul'tetov klynycheskoy psykholohy /Pod red. B. D. Karvasars'koho// - SanktPeterburh, 2006.

7. Yan'shyn P. V. Praktykum po klynycheskoy psykholohyy: Metodu yssledovanyya lychnosty / P. V. Yan'shyn// - SPb.: Pyter, 2004. - 331 s.

\section{Bondarenko Natalia}

PhD, Assistant of the Department of obstetrics and gynecology of Bogomolets National Medical University, Kyiv (Ukraine)

\section{Narytnyk Tetiana}

$P h D$, assistant of the Department of obstetrics and gynecology of Bogomolets National Medical University, Kyiv (Ukraine)

\section{Slobodianyk Oleh}

PhD, Associate professor of the Department of obstetrics and gynecology of Bogomolets National Medical University, Kyiv (Ukraine)

\section{Ziatdinova Mariana}

6 th year student of the Medical-Psychology Faculty of Bogomolets National Medical University, Kyiv (Ukraine)

\section{RESEARCH OF PSYCHOLOGICAL PECULIARITIES OF WOMEN IN PRECONCEPTION PREPARATION TO PREVENT THEIR PSYCHOSOMATIC DISORDERS DURING THE PREGNANCY}

\section{ABSTRACT}

Perform a brief theoretical analysis of the topic: how the physiological pregnancy proceeds, how the change in the hormonal background during fertilization and in the period of bearing the fetus affects the woman's emotional state. The work examines the psychological state and traits of the nature of women before conception and how this set of psychological qualities can affect the course, at the end of pregnancy and after birth, with a view to their possible correction in pre-school preparation. Significant role is paid to the accentuation of character, its relation to the appearance of qualitative path psychological changes at the time of pregnancy and after it. We consider the probability of occurrence of a mental illness in connection with the birth of a child. We develop methods of prevention and prevention of the emergence of mental states; studying prenatal matrices, as aiding a newborn mother in building a happy future for her child.

The psychic states combined the characteristics of mental processes and the characteristics of personality features. The analysis of the mental state allows to predict the behavior of the individual, its development and self-development. 
On the basis of mental process that dominated by women before pregnancy, psychic property is increasing and provokes the appearance mental states, which leads to the psychosomatic illness and the pathological course of pregnancy. So its possible to prevent the appearance of psychosomatic diseases and to give birth to a healthy child by researching the psychological peculiarities of non-pregnant women and by the timely detection of a pathologically altered mental state.

Confirmed that by exploring the psychological peculiarities of non-pregnant women and the timely detection of a pathologically altered mental state, in the implementation of these knowledge in pregravidinary preperation, it is possible to prevent the emergence of psychosomatic diseases and to give birth to a healthy child.

Key words: pregnancy, childbirth, postpartum condition, mental status, mental disorders, perinatal matrices, holotropic breathing, prevention, correction.

\section{Бондаренко Наталия Петровна}

Кандидат психологических наук, асистент кафедры акушерства и гинекологии Национального медицинского университета имени А. А. Богомольца, г. Киев (Украина)

\section{Нарытник Татьяна Теодоровна}

Кандидат психологических наук, асистент кафедры акушерства и гинекологии Национального медицинского университета имени А. А. Богомольцуа, г. Киев (Украина)

\section{Слободянык Олег Янович}

Кандидат медицинских наук, доиент кафедры акушерства и гинекологии № 1, Начионального медицинского университета имени А. А. Богомольц̧а, г. Киев, (Украина)

\section{Зиатдинова Марианна Руслановна}

Студент 6 курса медико-психологического факультета Национального медицинского университета имени А. А. Богомолеи, Киев (Украина)

\section{ИССЛЕДОВАНИЕ ПСИХОЛОГИЧЕСКИХ ОСОБЕННОСТЕЙ ЖЕНЩИН В ПРЕГРАВИДАРНОЙ ПОДГОТОВКЕ ДЛЯ ПРЕДУПРЕЖДЕНИЯ У НИХ ПСИХОСОМАТИЧЕСКИХ РАССТРОЙСТВ ВО ВРЕМЯ БЕРЕМЕННОСТИ}

Аннотация. Осуществляем краткий теоретический анализ темы: как протекает физиологическая беременность, как изменение гормонального фона во время оплодотворения и в периоде вынашивания плода влияет на эмоциональное состояние женщины. В работе исследуется психологическое состояние и черты характера женщин к зачатию и как этот набор психологических качеств может влиять на протекание, в завершение беременности и после рождения с целью их возможной коррекции в прегравидарная подготовке. Значительная роль отводится акцентуации характеpa, его отношение появления качественных патопсихологический изменений в момент беременности и после нее. Рассматриваем вероятность возникновения психической болезни в связи с рождением ребенка. Разрабатываем методы профилактики и предупреждения возникновения психических состояний; изучаем перинатальные матрицы, как помощь для новоиспеченной матери в прокладке счастливого будущего для своего ребенка. 
Ключевые слова: беременность, роды, послеродовое состояние, психическое состояние, психические расстройства, перинатальные матрицы, холотропное дыхание, профилактика, коррекция. 